v. 13, n. 1

Vitória-ES, Jan.-Feb. 2016

p. $69-91 \quad$ ISSN 1808-2386 DOI: http://dx.doi.org/10.15728/bbr.2016.13.1.4

\title{
Comparative Analysis of the Antecedents and Dimensions of Brand Equity Between Food Processors' Brands and Supermarket's Private Labels
}

\author{
José Sarto Freire Castelo \\ Fortaleza University \\ José Ednilson de Oliveira Cabral $^{\Omega}$ \\ Fortaleza University \\ Arnaldo Fernandes Matos Coelho ${ }^{¥}$ \\ Coimbra University
}

\begin{abstract}
This paper evaluates the relationship between the marketing mix elements and the creation of brand equity based on a conceptual framework defined from the state of the art marketing literature. The study is based on individual perceptions of 603 buyers who had the experience in the context of an assisted "top of mind" of six brands of food processors versus the private label of a supermarket in the city of Fortaleza - Ceará. The results of the hypotheses tests, with the application of the structural equation modeling, show that the marketing mix elements relate differently to the dimensions that antecedents brand equity, and that the perceived quality and brand association dimensions are similar in the formation of brand equity of manufacturers and supermarket's food brands.
\end{abstract}

Keywords: Brand. Brand equity. Private label. Manufacturer's brand.

* Author for Correspondence:

$\dagger$. Doctor in Management with emphasis in Marketing by Faculdade de Economia da Universidade de Coimbra. Institution: Professor Adjunto I da Universidade de Fortaleza Address: Av. Washington Soares, 1321. Edson Queiroz

60811-905 Fortaleza, CE - Brazil.

E-mail: sarto@unifor.br

Telefone: +55 (85) 3477 - 3192

\footnotetext{
${ }^{\Omega} \mathrm{PhD}$. The University of Reading - UK; Pós-Doutor The University of Sussex - UK Institution: Professor Titular da Universidade de Fortaleza Address: Rua Eduardo Salgado, no. 303/902, Fortaleza - CE - Brazil CEP 60150-140.

E-mail: ednilsoncabral@gmail.com

Telephone: +55 (85) 981809979
}

\author{
¥ Doctor em "Ciências Económicas y \\ Empresariales" pela Universidade de \\ Barcelona - Espanha \\ Vínculo: Professor Auxiliar da \\ Faculdade de Economia da \\ Universidade de Coimbra. \\ Adress: Av. Dias da Silva, 165. 3004- \\ 512. Coimbra-Portugal \\ E-mail: acoelho@fe.uc.pt \\ Telephone: : +351239790576
}

Note from the Editor: The article was accepted by Emerson Mainarde. 


\section{INTRODUCTION}

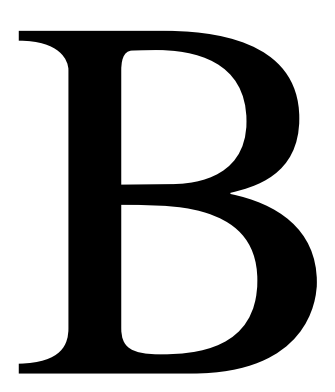

rand equity is considered as one of the main sources of differentiation and of sustainable competitive advantage for companies (SHIMP, 1999; SCHULTZ, 2001). For Muniz and Marchetti (2012), given the intensification of the competition, global consumers are faced with an increasing availability of similar alternative products to satisfy their needs and desires, placing on the label an increased differentiator element role, going way beyond its rational and functional aspects. These characteristics, together, generate equity or brand value.

Brand equity refers to obtaining a premium price for a brand, compared to that which would be obtained if the product or service was not identified by a brand (AAKER, 1991; KELLER, 1993; AAKER; BREL, 1993). Brands, according to Rumelt, Schendel and Teece (1991), are parts of the strategic assets responsible for developing competitive advantages in organizations. Thus, an important issue for the Academy and marketers is how to build brand equity. In this way, it is essential to know the antecedents and determinants of brand equity.

Thus, this paper approaches the identification, evaluation and comparison of the impact of the antecedents and determinants of brand equity, in supermarket's private labels versus manufactures' brands from the food sector. Among these antecedents, we find the company's marketing efforts contemplated in their marketing mix, while among the determinants the dimensions of brand equity are included.

The election of the theme is based on the fact that, given the potential impact of the brand, as already noted, one of the most important goals for companies in general is to increase the brand equity. However, there is a gap in the marketing literature to compare the antecedents and determinants of different categories of brands as in the case for supermarkets and manufacturers' brands.

Despite studies on private brands dating back to the 1960s, with studies among others by Cunningham (1961), Frank and Boyd (1965), Myers (1967), up to our present days, for example studies by Sayman and Raju (2004), Hansen, Singh and Chintagunta (2006), Ailawadi, Pauwels and Steenkamp (2008), Steenkamp, Van Heerde e Geyskens (2010) and Manikandan (2012), only in 1996 the issue gained prominence with the study by Quelch and Harding (1996), warning about the dispute between retailers and manufacturers' private labels. This study showed that private labels in the United States responded for greater individual market shares than the strongest national brands, for 77 out of 250 supermarket 
products categories, and occupy the second and third place in 100 of these categories. Grewal and Levy (2007) encourages further studies on private labels for it provides a direct impact on sales and profitability of the retail sector.

One of the main determinants for this growth, pointed out in literature, is the lower price practiced by private labels. According to AcNielsen (2005), the prices practiced in 80 categories of private label products, in 38 of the surveyed countries were on average $31 \%$ below the prices of similar products of traditional manufacturers' brands. Lower prices in these countries range from $10 \%$ in Hong Kong as low as $50 \%$ in Poland. Private labels present a market share in units at $21.3 \%$ and $16.4 \%$ in US\$ in supermarkets in 2006 (PLMA Yearbook, 2007). However, brand equity is determined by a set of factors apart from price.

In view of this context, we propose the following questions for the study: Are the factors influencing the determinants of brand equity distinguishable between food manufactures' brands and supermarkets' private labels? Are there different determinants of brand equity for food manufactures' brands and supermarkets' private labels?

From these questions, we formulate the following general objective: to conduct a comparison of the antecedents and the determinants of brand equity in food products, between manufactures' brands supermarket private labels.

In addition to this this introduction, this paper is organized as follows: part 1 presents the antecedents and determinants of brand equity, which are the basis for the formulation of the hypotheses and consequent conceptual model of the study; part 2 presents the research methodology, contemplating items such as data collection procedures, sample and analytic technique; part 3 presents the analysis of the results; and part 4 finishes the paper with the final considerations.

\section{LITERATURE REVIEW AND HYPOTHESES}

Brand equity refers to obtaining a superior value for a brand compared to that which would be obtained if the product or service was not identified by that brand (AAKER, 1991; KELLER, 1993; AAKER; BREL, 1993). In this sense, Yoo, Donthu and Lee (2000), developed a conceptual framework of brand equity from Aaker's model (1991) (Figure 1). Originally, Aaker (1991) suggested that first of all, brand equity generates value both for the company as well as for the client. As a first step, the company ensures a certain proposal of customer value. As a second step, customer's satisfaction and loyalty create value for the company's brand. 
Yoo, Donthu and Lee (2000) expanded Aaker's model (1991) from two different perspectives. At first these authors separated the concept of brand equity placing it between the "dimension of brand equity" and the "values generated for customers and for the company". This separation shows that the concept of brand equity relates individually with the dimensions of brand equity. This model shows how the dimensions of brand equity contribute for the company's value. In addition, Yoo, Donthu and Lee (2000) inserted as antecedents to these dimensions marketing activities which in their opinion has significant effects on the dimensions of brand equity.

The selected activities of the marketing mix are prices, store image, distribution intensity, advertising expenses and rice promotions or negotiations. Despite these variables not meeting the complete marketing domain, they represent typical actions of companies' strategies with great impact potential on brand image. Given that these marketing activities contribute to brand equity, their creative and refined form of management enables the development of more effective marketing plans. Marketing managers should therefore, promote activities that help building and solidifying brand equity through a consequent management of the company's marketing plans.

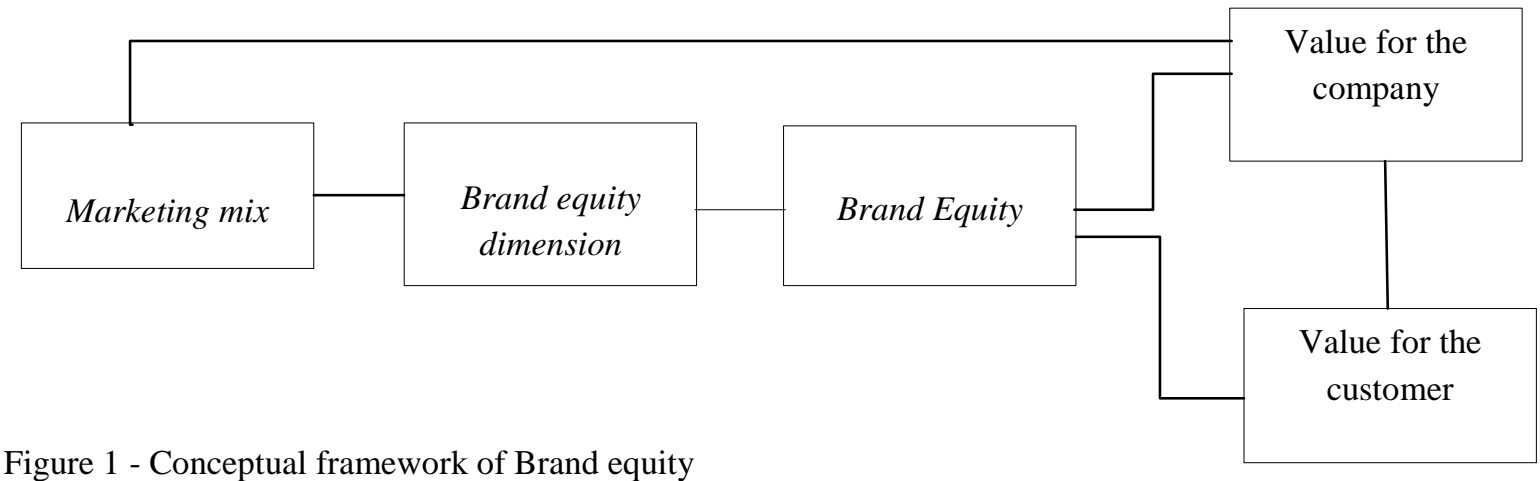

Figure 1 - Conceptual framework of Brand equity

Source: Yoo, Donthu and Lee (2000). Adapted by authors.

Yoo, Donthu and Lee (2000) define brand equity as the difference in the choice by the consumer between a branded and non-branded product, given the same level of product characteristics. This definition deals with the comparison between two products that are identical in all aspects, except for the brand (for example, Lacoste product compared to a product without a brand). All consumers have an impression of what Lacoste transmits about a product, which is different from that transmitted by a nameless product. The brand equity by the Lacoste brand is the extra value incorporated in its name, as it is perceived by the consumer, in comparison to an identical, though nameless product. The difference in the 
consumer's choice on these two products may be assessed by measuring the purchase intention or the preference for the brand by comparison against a nameless product.

According to Aaker (1991) brand equity is a multidimensional concept. It consists in the perceived quality, in the knowledge of the brand, in associations to the brand and other assets related to the brand. Other researchers identified similar dimensions. Shocker and Weitz (1988) proposed brand loyalty and brand associations and Keller (1993) suggested brand knowledge, comprising brand awareness and brand image. Yoo, Donthu and Lee (2000) acknowledge brand loyalty, perceived quality, brand knowledge and the positive brand associations are the most common dimensions of brand equity.

For Yoo, Donthu, and Lee (2000) high brand equity implies that customers have strong and positive associations related to the brand; they perceive the brand as being of high quality, and therefore are loyal to the brand. In this context, the model shown in Figure 1 conveys the idea that the dimensions of brand equity increase it, for each one of these dimensions is positively related to it.

A marketing action is positively related to brand equity when it leads to a more favorable behavioral response to the product. As proposed in the conceptual framework, managerial efforts are manifested in marketing activities that are controlled and related to the brand image, through the mediation of the dimensions of brand equity. Therefore, in order to create, manage and exploit brand equity, the impacts of marketing efforts in the dimensions of brand equity must be determined (YOO, DONTHU and LEE, 2000). In this sense, literature presents the following proposal.

\section{Price}

Customers use price as an extrinsic important signaling of the quality and benefits of the products. High-priced brands are generally considered to have higher quality and lower vulnerability to fluctuations in price, competing with an advantage against low-priced brands (OLSON, 1977; KAMAKURA; RUSSELL, 1993; ANSELMSSON, JOHANSSON; PERSSON, 2007; CHEN; GREEN, 2009). Rao and Monroe (1989) identified a positive relation between price and the perceived quality. As long as the premium price is equally associated with a premium quality, therefore, price is indirectly associated with brand equity. Therefore, we propose the following hypotheses:

H1a and H1b. There is a positive relationship between the high prices of the manufacturers' brands (private) and the perceived quality of these brands. 
However, Yoo, Donthu and Lee (2000), in their research, verified that the alterations of the price levels do not affect or have a lesser impact on brand loyalty, as well as there being no directional relationship between price and brand associations. Thus, hypotheses are not formulated for the relations of prices to these dimensions.

\section{Stores' image}

An efficient administration of the distribution channel amongst the marketing tools contributes for the increase of brand equity (SRIVASTAVA; SHOCKER, 1991). In a distribution channel, retailers find the company's final consumers. In particular, the distribution through stores with a good image is quality signalization. Snipes, Thomson and Oswald (2006) and Chen and Green (2009) found significant positive effects of store image on perceived quality. The store's name is a vital extrinsic clue of the perceived quality. It is perceived differently depending on what the retailer offers.

A good store image attracts more attention, contacts and visits from potential customers. In addition, these stores provide greater satisfaction to consumers and stimulate positive word-of-mouth among consumers (ZEITHAML, 1988; RAO; MONROE, 1989). Therefore, the distribution of a brand through stores with a good image will create more positive brand associations (YOO; DONTHU; LEE, 2000). The store image can be considered an important predictor of attitude in relation to a store brand (SEMEIJN; RIEL; AMBROSINI, 2004). Given this ground, we propose the following hypotheses:

$\mathrm{H} 2 \mathrm{a}$ and $\mathrm{H} 2 \mathrm{~b}$. There is a positive relationship between the store's image of the manufacturers' brands (private) and the perceived quality of these brands;

$\mathrm{H} 3 \mathrm{a}$ and H3b. There is a positive relationship between the store's image of the manufacturers' brands (private) and the associations of these brands.

\section{Distribution intensity}

Distribution is said to be intensive when products are placed in a large number of stores to cover the market. In order for retailers to improve the image of a given product and to obtain substantial support prefer a more exclusive or selective distribution and not in an intensive way. Consumers are more satisfied, however, when a product is available in a larger number of shops, as it increases the accessibility of products (FERRIS; OLIVER; KLUYVER, 1989; SMITH, 1992; CHEN; GREEN, 2009). Intensive distribution shortens the search time of shops, providing convenience in the purchase and making it easy to get the services or products. As soon as the distribution intensity increases, consumers have more 
time and perceive more value in products. This higher value leads to a greater customer satisfaction, a higher perceived quality, to a greater brand loyalty, more positive associations, and consequently to a greater brand equity (YOO; DONTHU; LEE, 2000). Thus we propose the following hypotheses:

$\mathrm{H} 4 \mathrm{a}$ and H4b. There is a positive relationship between the distribution intensity of the manufacturers' brands of (private) and the perceived quality of these brands;

$\mathrm{H} 5 \mathrm{a}$ and $\mathrm{H} 5 \mathrm{~b}$. There is a positive relationship between the distribution intensity of the manufacturers' brands of (private) and brand loyalty;

H6a and H6b. There is a positive relationship between the distribution intensity of the manufacturers' brands of (private) and brand association.

\section{Expenses with advertising}

High investments in advertising indicate that the company is leveraging the brand, which translates into a higher quality (KIRMANI; WRIGHT, 1989). In addition, Archibald, Haulman and Moody (1993) found that the levels of advertising expenses are good signals not only of superior quality but also of a good purchase. Aaker and Jacobson (1994), Belch and Belch (2007) and Chen and Green (2009) also found a positive relationship between advertising and the perceived quality Thus, advertising expenditures are positively related to the perceived quality and also increment the brand equity.

Yoo, Donthu and Lee (2000) propose that advertising plays a key role in creating strong brand associations. These sets of assertions lead to the following hypotheses:

$\mathrm{H} 7 \mathrm{a}$ and $\mathrm{H} 7 \mathrm{~b}$. There is a positive relationship between advertising expenditures of the manufacturers' brands (private) and the perceived quality of these brands.

H8a and H8b. There is a positive relationship between advertising expenditures of the manufacturers' brands (private) and brand loyalty.

$\mathrm{H} 9 \mathrm{a}$ and $\mathrm{H} 9 \mathrm{~b}$. There is a positive relationship between advertising expenditures of the manufacturers' brands (private) and associations of these brands.

\section{Negotiated prices}

Sales promotion, in particular, price promotions or negotiated prices (for example, the reduction of prices for a short-term, special sales, distributed coupons, offers, discounts and restitutions) undermine brand equity over time, despite the immediate short-term gains. Sales 
promotions cannot be a convenient way to build brand equity, for it is easily copied and performance in the long run is neutralized (AAKER, 1991). Therefore, long-term sales promotions can transmit an image of a low quality product. In turn, Shimp (1997) suggests that promotional campaigns do not last long enough to establish positive long-term brand associations. Therefore we have formulated the following hypotheses:

$\mathrm{H} 10 \mathrm{a}$ and H10b. There is a negative relationship between negotiated prices of the stores of the manufactures' brand (private) and the perceived quality of these brands.

$\mathrm{H} 11 \mathrm{a}$ and H11b. There is a negative relationship between negotiated prices of the stores of the manufactures' brand (private) and the associations with these brands.

Immediately, according to Yoo, Donthu and Lee (2000), price promotions are not related to brand loyalty, though it is used consistently in order to force a temporary brand exchange. Promotions often fail to establish a repeated purchasing pattern, after an initial judgment by the consumer. This is because consumers are momentarily drawn to the brand by the utilitarianism of the transaction resulting from price promotions, and once the promotion is over consumers lose their interest for the brand.

\section{Brand equity dimensions}

The adequate understanding of the brand equity phenomenon requires the knowledge of its determinants: loyalty, perceived quality, knowledge and brand associations (AAKER, 1991).

Zeithaml (1988) defines the perceived quality as a judgment (subjective) on the overall excellence of a product or its superiority recognized by the consumer. According to Yoo, Donthu and Lee (2000), personal experience with products, the specific needs and situations of consumption can influence the subjective judgment of the consumer on the quality. A high perceived quality means that through a long-term experience with the brand, consumers recognize differentiation and superiority of the brand. Also in this line of thought, perceived quality is identified as a component of brand value and therefore, a high perceived quality leads consumers to select one brand over other competing brands. Therefore, the degree of quality at which the brand is perceived by consumers contributes positively to brand equity (CHEN; GREEN, 2009).

Loyalty is defined by Oliver (1997) by 
the deep-seated commitment to repeat the purchase of a preferred product or service, consistently over time despite situational influences and marketing efforts to change consumer behavior.

Brand loyalty causes consumers to buy a brand routinely, and to be resistant to change to another brand. Thus, as consumers become loyal to the brand, they provide an increase in brand equity (DATTA, 2003).

Aaker (1991) defines brand associations as "anything connected to the memory of a brand". Brand associations are complex and linked to one another and consist of several ideas, episodes, events and facts that establish a solid network of brand awareness. The associations are stronger when they are based on many experiences, or exposure in the media (ALBA; HUTCHINSON, 1987; AAKER, 1991). Brand associations that result in high brand awareness are positively related to brand equity. It y can be a sign of quality and commitment and help a buyer to consider the brand at the point of purchase, which leads them to a favorable behavior for the brand (WALSH; MITCHELL, 2005). This positive awareness of brand associations is expressed in the proposal by Yoo, Donthu and Lee (2000) to measure them, using associations and knowledge scales, to a brand that will lead to recognition according to the interpretation of the brand as a signification device.

The theoretical propositions above are empirically reinforced, in the researches by Atilgan et al. (2005) who, from a sample of university students from Turkey, concluded that loyalty, awareness and perceived quality are important determinants of brand equity in general. From the above, it formulated the following hypotheses:

$\mathrm{H} 12 \mathrm{a}$ and H12b. There is a positive relationship between the perceived quality of the manufacture's brand (private) and the manufacture's brand equity (private);

H13 a and H13b. There is a positive relationship between the manufacture's brand loyalty (private) and the manufacture's brand equity (private);

$\mathrm{H} 14 \mathrm{a}$ and H14b. There is a positive relationship between the manufacture's brand associations (private) and the manufacture's brand equity (private).

The formulated hypotheses are graphically represented in Figure 2. 


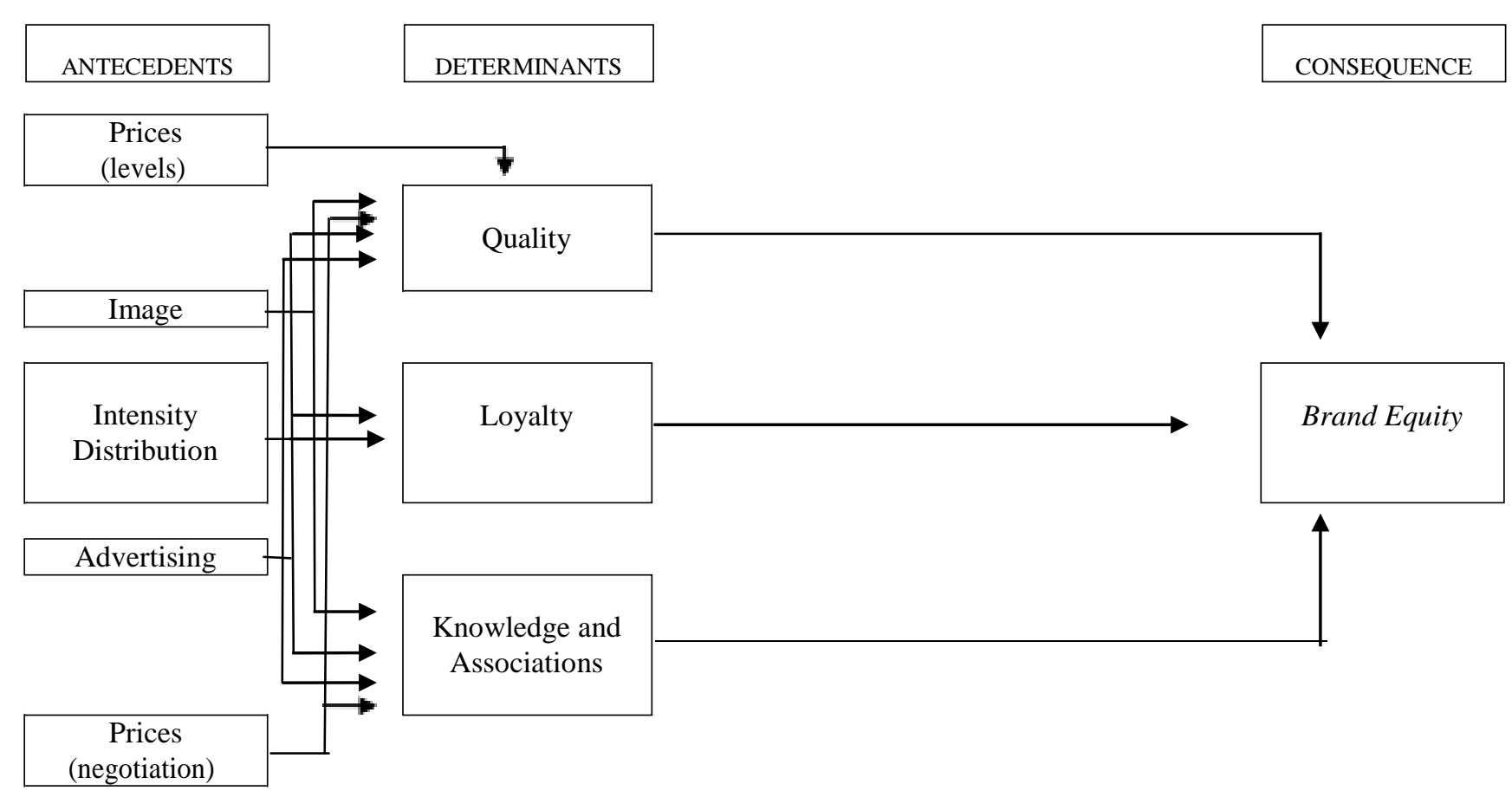

Figure 2 - Conceptual research model

\section{METHODOLOGICAL FRAMEWORK OF THE RESEARCH}

For the target population we defined men and women above 15 years of age who reside in several neighborhoods in the city of Fortaleza, who had done their food shopping at the Carrefour supermarket, located on Av. Barão Studart. Given the lack of information a priori about the identification on the population individuals, required by the application of probability sampling technique, the sample was defined as of non-probabilistic nature for convenience. (MALHOTRA, 2012).

For the data collection we applied structured undisguised questionnaires, always with the same questions and response options (MATTAR; OLIVEIRA; MOTTA, 2014). In order to apply the questionnaires we used two scholarship students of the research programs of the University of Fortaleza. Duly identified they personally presented, applied and collected the questionnaires, without oral interference, leaving the 651 volunteers at ease to answer the survey. A total of 603 questionnaires were validated, since 48 were eliminated by filling imperfections. This sample size was defined in order to comply with the minimum requirements of at least five respondents for each estimated parameter (HAIR JUNIOR et al., 2005). Among the respondents, 51.1\% are female, 54.2\% were aged between 20 and 34 years, $67.5 \%$ had finished their second to last high school year or the last high school year incomplete, $67.7 \%$ held a family income 3-20 times the minimum wage. This sample comprises $70 \%$ of the geographical area, given the participation of residents from the 114 
neighborhoods, and of these $98.7 \%$ had bought food brands by manufacturers who first came to his mind and $43.1 \%$ had bought Carrefour supermarket food brands.

The constructs were measured by Likert scale of 5 points - with 1 , meaning totally disagree and 5, totally agree, formed by multiple items. All items are evaluated by representative studies from literature. Thus, the constructs of the marketing mix, manufacturer's prices and Carrefour (PMSf and PMSC), store's image (IMSf and IMSC), distribution intensity (IDMSf and IDMSC), expenses with advertising (GPMSf and GPMSC) and negotiated prices (PNMSf and PNMSC); the constructs of brand equity (BEMSf and BEMSC); and the brand determinants constructs, perceived quality (QPMSf and QPMSC), and loyalty (LMSf and LMSC) and knowledge and associations (ACMSf and ACMSC) are the ones developed by Yoo, Donthu and Lee (2000).

In the hypotheses test of the proposed model we used a structural equation modeling (SEM) which is a multivariate technique that combines the exploratory factor analysis to estimate a set of simultaneous equations. We considered SEM the appropriate analytical technique and most efficient for this research, because the model has a separate set of multiple regression equations, but interdependent that must be simultaneously estimated (HAIR JUNIOR et al., 2005).

The analysis began with the measurement model, by applying the confirmatory factor analysis (CFA) to verify the psychometric properties of the scales and test the pre-established relationships (HAIR JUNIOR et al., 2005). The adjustment indexes are within the range of values considered satisfactory (Table 1).

Table 1 - Adjustment Measures of the Measurement Model of Manufactures' Brands vs. Private Labels

\begin{tabular}{l|rr}
\hline Measures & \multicolumn{2}{|c}{ Brands } \\
\hline Absolute adjustments & Manufactures & Supermarket private labels \\
\hline Chi-squared $\left(x^{2}\right)$ & 1328.015 & 1352.872 \\
Degrees of freedom & 490.948 & 491.061 \\
CMIN/DF & 2.705 & 2.755 \\
Significance level $(p$ value) & 0,000 & 0.000 \\
GFI & 0.883 & 0.883 \\
RMSEA & 0.053 & 0.054 \\
RMR or SRMR & 0.038 & 0.038 \\
\hline Incremental adjustment & & 0.858 \\
\hline AGFI & 0.859 & 0.936 \\
TLI or NNFI & 0.936 & 0.916 \\
NFI & 0.914 & 0.944 \\
CFI & 0,944 & 0.801 \\
\hline Parsimonious adjustment & & 0.729 \\
\hline PNFI & 0.800 & 1560.872 \\
PGFI & 0.729 & 1536.015 \\
AIC & & \\
\hline SOurce: Fild & & \\
\hline
\end{tabular}

Source: Field research. 
Hair Junior et al. (2005) recommend that as soon as the general adjustment model has been analyzed, measurement of each construct can then be evaluated for one-dimensionality and reliability. Thus, we proceeded with the discriminant validity of the constructs that make up the final model. We found that the correlation table between each pair of constructs is lower than the extracted variance of each one of them reaching compatible results with the accepted literature (extracted variance greater than 0.5 and the compound reliability exceed $0.7)$, Tables 2 and 3.

Table 2 - Discriminant Validity of the Constructs of Supermarket Manufacturers' Brand

\begin{tabular}{lcccccccccccc}
\hline & SD & PMSf & IMSf & IDMSf & GPMSf & PNMSf & QPMSf & LMSf & ACMSf & BEMSf & CR & EV \\
\hline PMSf & 0.957 & $\mathbf{0 . 8 9 1}$ & & & & & & & & & 0.897 & 0.746 \\
IMSf & 0.727 & 0.149 & $\mathbf{0 . 8 4 5}$ & & & & & & & & 0.848 & 0.651 \\
IDMSf & 0.744 & 0.168 & 0.333 & $\mathbf{0 . 8 9 3}$ & & & & & & & 0.893 & 0.735 \\
GPMSf & 0.869 & 0.135 & 0.126 & 0.351 & $\mathbf{0 . 8 8 2}$ & & & & & & 0.888 & 0.727 \\
PNMSf & 0.970 & -0.045 & 0.028 & 0.065 & 0.381 & $\mathbf{0 . 8 2 1}$ & & & & & 0.834 & 0.630 \\
QPMSf & 0.516 & 0.106 & 0.07 & 0.125 & 0.056 & 0.033 & $\mathbf{0 . 9 2 1}$ & & & & 0.925 & 0.675 \\
LMSf & 1.021 & 0.047 & 0.078 & 0.019 & 0.061 & 0.005 & 0.060 & $\mathbf{0 . 9 1 2}$ & & & 0.916 & 0.785 \\
ACMSf & 0.688 & 0.137 & 0.188 & 0.245 & 0.135 & 0.025 & 0.000 & 0.119 & $\mathbf{0 . 9 3 5}$ & & 0.937 & 0.712 \\
BEMSf & 1.063 & 0.032 & 0.139 & 0.274 & 0.181 & 0.081 & 0.078 & 0.022 & 0.155 & $\mathbf{0 . 9 3 5}$ & 0.956 & 0.807 \\
\hline
\end{tabular}

Source: Field Research. Note: The main diagonal shows the Cronbach's alpha; SD = Standard deviation; $\mathrm{CR}=$ Compound Reliability; EV = Extracted Variance.

Table 3 - Discriminant Validity of the Constructs of Supermarket's Brand

\begin{tabular}{|c|c|c|c|c|c|c|c|c|c|c|c|c|}
\hline & SD & PMSC & IMSC & IDMSC & GPMSC & PNMSC & QPMSC & LMSC & ACMSC & BEMSC & CR & EV \\
\hline PMSC & 0.777 & 0.893 & & & & & & & & & 0.899 & 0.749 \\
\hline IMSC & 0.709 & -0.049 & 0.847 & & & & & & & & 0.852 & 0.659 \\
\hline IDMSC & 0.962 & 0.226 & -0.061 & 0.883 & & & & & & & 0.884 & 0.718 \\
\hline GPMSC & 0.806 & 0.218 & -0.051 & 0.455 & 0.890 & & & & & & 0.896 & 0.743 \\
\hline PNMSC & 1.064 & -0.002 & -0.009 & 0.118 & 0.317 & 0.820 & & & & & 0.865 & 0.685 \\
\hline QPMSC & 0.931 & 0.072 & 0.105 & 0.132 & 0.123 & 0.003 & 0.923 & & & & 0.930 & 0.691 \\
\hline LMSC & 1.028 & 0.003 & -0058 & 0.086 & 0.108 & -0.007 & 0.079 & 0.919 & & & 0.922 & 0.798 \\
\hline ACMSC & 0.965 & 0.099 & -0.001 & 0.067 & 0.111 & -0.042 & 0.059 & 0.049 & 0.936 & & 0.938 & 0.716 \\
\hline BEMSC & 1.000 & 0.099 & 0.036 & 0.238 & 0.163 & 0.023 & 0.144 & 0.139 & 0.129 & 0.936 & 0.958 & 0.815 \\
\hline
\end{tabular}

Source: Field Research. Note: The main diagonal shows the Cronbach's alpha; SD = Standard deviation; $\mathrm{CR}=$ Compound Reliability; EV = Extracted Variance.

From the results above, we proceeded to the examination of the overall performance of the structural model of the manufacturer brands and the supermarket. The absolute adjustment measures (indicate the degree to which the model predicts a covariance matrix or correlation) these were made appropriate, with indexes at acceptable peripheral levels, since there is no established reference (HAIR JUNIOR et al., 2005). However Hair Junior et al. (2005) claim that the measure applicable to assess a single model is the $\chi^{2}$ measure normed with upper limit 
a5. Therefore, the three general types of measures for adjustment observed reveal a consistent pattern to support the model of the manufacturing vs. supermarkets' brands (Table 4).

Table 4 - Adjustment Measures of the Structural Model of the Manufacturers vs. Supermarkets' Brands

\begin{tabular}{l|rr}
\hline Measures & \multicolumn{2}{|c}{ Brands } \\
\hline Absolute adjustment & Manufacture & Private for the supermarket \\
\hline Chi- squared $\left(x^{2}\right)$ & 1616,545 & 1594,337 \\
Degree of freedom & 516,000 & 515,000 \\
CMIN/DF & 3,133 & 3,096 \\
Significance level $(p$ value) & 0,000 & 0,000 \\
GFI & 0,862 & 0,865 \\
RMSEA & 0,060 & 0,059 \\
RMR r SRMR & 0,097 & 0,091 \\
\hline Incremental adjustment & & 0,844 \\
\hline AGFI & 0,841 & 0,924 \\
TLI or NNFI & 0,920 & 0,901 \\
NFI & 0,895 & 0,930 \\
CFI & 0,926 & 0,827 \\
\hline Parsimonious adjustment & & 0,749 \\
\hline PNFI & & 1754,337 \\
PGFI & 0,823 & 0,748 \\
AIC & 1774,545 & \\
\hline
\end{tabular}

Source: Field research.

\section{ANALYSIS AND DISCUSSION OF RESULTS}

The results analysis will follow the sequence of the formulated hypotheses, with special emphasis on the differences between manufacturers and supermarkets' brand to the possible explanations for the cases that have come to reveal a conduct contrary to expectations. In the first part, we will analyze the relationship between the antecedents (marketing mix components in companies) and the dimensions of brand equity; the second will analyze the results of the hypothesis test between determinants (dimensions) and value of brands (brand equity). Table 5 shows the results of the hypotheses tests.

\subsection{PRICE AND QUALITY}

The hypothesized relationship between price levels and quality were opposed to the manufacturers' brand (H1a) and for supermarkets' brands (H1b), that is, H1a (support, yes) and H1b (support, no), at significance levels of 5\%. Therefore, one cannot infer, from the high price that there may be a higher product quality, whether it is the manufactures or the supermarkets' brands. The evidence points to the maxim that the consumer is guided by the relationship "paying for what is worth", that is, the highest or lowest price reflects the level of quality associated. Thus, a higher price does not necessarily mean higher quality. Another possible factor in the divergence of the hypothesis is the smallest precision design of the concepts of price and quality, as these concepts are ambiguous, i.e., not easily assimilated in a 
unison way by the consumer (SWINKER; HINES, 2006). In addition, the consumer in general has perceptions regarding price as a sacrifice to obtain a product and, thus, imprecise adjectives related to quality are easily made confused, which is a multidimensional concept (YOO; DONTHU; LEE, 2000).

Table 5 - Structural Model of the Manufacturing Supermarkets' Brands and Carrefour

\begin{tabular}{|c|c|c|c|c|c|c|c|c|c|c|c|c|c|}
\hline \multirow[b]{2}{*}{ Hyphothesis } & \multicolumn{5}{|c|}{ Supermarket Manufacturers' brands } & \multirow[b]{2}{*}{$\begin{array}{l}\text { Hypothesis } \\
\text { Support }\end{array}$} & \multicolumn{7}{|c|}{ Carrefour Supermarket brands } \\
\hline & & & $\begin{array}{c}\text { Standardized } \\
\text { coefficient }\end{array}$ & C.R. & $\mathrm{P}$ & & Hypothesis & & & $\begin{array}{l}\text { Standardized } \\
\text { coefficient }\end{array}$ & C.R. & $\mathrm{P}$ & $\begin{array}{l}\text { Hypothesis } \\
\text { Support }\end{array}$ \\
\hline H1st. PMSf & $--->$ & $\begin{array}{l}\text { QPMS } \\
\text { f (+) } \\
\text { QPMS }\end{array}$ & 0.043 & 2.03 & 0.043 & Yes & H1b. PMSC & $\begin{array}{l}-- \\
>--\end{array}$ & $\begin{array}{l}\text { QPMS } \\
\text { C (+) } \\
\text { QPMS }\end{array}$ & 0.047 & 0.91 & 0.363 & Not \\
\hline H2nd. IMSf & $-->$ & $\begin{array}{l}f(+) \\
\text { ACMS }\end{array}$ & 0.019 & 0.62 & 0.536 & Not & H2.b IMSC & $>$ & $\begin{array}{l}\mathrm{C}(+) \\
\text { ACMS }\end{array}$ & 0.153 & 2.61 & 0.009 & Yes \\
\hline H3rd. IMSf & $--->$ & $\begin{array}{l}f(+) \\
\text { QPMS }\end{array}$ & 0.122 & 2.76 & 0.006 & Yes & $\begin{array}{l}\text { H3b. IMSC } \\
\text { H4b. }\end{array}$ & $>$ & $\begin{array}{l}\text { C (+) } \\
\text { QPMS }\end{array}$ & 0.009 & 0.14 & 0.887 & Not \\
\hline H4th. IDMSf & $-->$ & $\begin{array}{l}\mathrm{f}(+) \\
\text { LMSf }\end{array}$ & 0.069 & 2.3 & 0.022 & Yes & $\begin{array}{l}\text { IDMSC } \\
\text { H5b. }\end{array}$ & $>$ & $\begin{array}{l}\mathrm{C}(+) \\
\mathrm{LMSC}\end{array}$ & 0.094 & 2.21 & 0.027 & Yes \\
\hline H5th. IDMSf & $--->$ & $\begin{array}{l}(+) \\
\text { ACMS }\end{array}$ & 0.005 & 0.08 & 0.933 & Not & $\begin{array}{l}\text { IDMSC } \\
\text { H6b. }\end{array}$ & $\begin{array}{l}> \\
---\end{array}$ & $\begin{array}{l}(+) \\
\text { ACMS }\end{array}$ & 0.056 & 1.17 & 0.242 & Not \\
\hline H6th. IDMSf & $--->$ & $\begin{array}{l}\mathrm{f}(+) \\
\text { QPMS }\end{array}$ & 0.184 & 4.36 & $* * *$ & Yes & $\begin{array}{l}\text { IDMSC } \\
\mathrm{H} 7 \mathrm{~b} .\end{array}$ & $>$ & $\begin{array}{l}\mathrm{C}(+) \\
\text { QPMS }\end{array}$ & 0.026 & 0.57 & 0.568 & Not \\
\hline H7th. GPMSf & $--->$ & $\begin{array}{l}\text { f }(+) \\
\text { LMSf }\end{array}$ & 0.002 & 0.06 & 0.952 & Not & $\begin{array}{l}\text { GPMSC } \\
\text { H8b. }\end{array}$ & $>$ & $\begin{array}{l}\mathrm{C}(+) \\
\text { LMSC }\end{array}$ & 0.106 & 2.12 & 0.034 & Yes \\
\hline H8th. GPMSf & $--->$ & $\begin{array}{l}(+) \\
\text { ACMS }\end{array}$ & 0.07 & 1.33 & 0.185 & Not & $\begin{array}{l}\text { GPMSC } \\
\text { H9b. }\end{array}$ & $>$ & $\begin{array}{l}(+) \\
\text { ACMS }\end{array}$ & 0.113 & 2.03 & 0.042 & Yes \\
\hline H9th. GPMSf & $--->$ & $\begin{array}{l}\mathrm{f}(+) \\
\text { QPMS }\end{array}$ & 0.059 & 1.64 & 0.1 & Not & $\begin{array}{l}\text { GPMSC } \\
\text { H10b. }\end{array}$ & $>$ & $\begin{array}{l}\mathrm{C}(+) \\
\text { QPMS }\end{array}$ & 0.151 & $\begin{array}{r}2.85 \\
-\end{array}$ & 0.004 & Yes \\
\hline H10th. PNMSf & $--->$ & $\begin{array}{l}\mathrm{f}(-) \\
\mathrm{ACMS}\end{array}$ & 0.016 & 0.68 & 0.496 & Not & $\begin{array}{l}\text { PNMSC } \\
\text { H11b. }\end{array}$ & $>$ & $\begin{array}{l}\mathrm{C}(-) \\
\text { ACMS }\end{array}$ & $-0,028$ & $\begin{array}{r}0,76 \\
-\end{array}$ & 0.45 & Not \\
\hline H11th. PNMSf & $--->$ & $\begin{array}{l}\text { f (-) } \\
\text { BEMS }\end{array}$ & $-0,010$ & $-0,3$ & 0.763 & Not & $\begin{array}{l}\text { PNMSC } \\
\text { H12b. }\end{array}$ & $\begin{array}{l}> \\
---\end{array}$ & $\begin{array}{l}\mathrm{C}(-) \\
\text { BEMS }\end{array}$ & $-0,073$ & 1,82 & 0.068 & Not \\
\hline H12th. QPMSf & $-->$ & $\begin{array}{l}\mathrm{f}(+) \\
\text { BEMS }\end{array}$ & 0.168 & 1.83 & 0.067 & Yes & $\begin{array}{l}\text { QPMSC } \\
\text { H13b. }\end{array}$ & $\begin{array}{l}> \\
---\end{array}$ & $\begin{array}{l}\mathrm{C}(+) \\
\text { BEMS }\end{array}$ & 0.139 & 3.05 & 0.002 & Yes \\
\hline H13th. LMSf & $--->$ & $\begin{array}{l}\mathrm{f}(+) \\
\text { BEMS }\end{array}$ & 0.001 & 0.01 & 0.991 & Not & $\begin{array}{l}\text { LMSC } \\
\text { H14b.CMS }\end{array}$ & $\begin{array}{l}> \\
---\end{array}$ & $\begin{array}{l}\text { C (+) } \\
\text { BEMS }\end{array}$ & 0.122 & 2.94 & 0.003 & Yes \\
\hline H14th. ACMSf & $--->$ & $\mathrm{f}(+)$ & 0.238 & 3.64 & $* * *$ & Yes & $\mathrm{C}$ & $>$ & $\mathrm{C}(+)$ & 0.12 & 2.76 & 0.006 & Yes \\
\hline
\end{tabular}

Source: Research data. (t) Value used 1.65 at significance level for $(\mathrm{p}<0,05)$.

\subsection{IMAGE AND QUALITY}

Unlike the result of price and quality, the hypotheses that image relates to quality, we did not confirm it for ( $\mathrm{H} 2 \mathrm{a})$ for manufactures and confirmed for $(\mathrm{H} 2 \mathrm{~b})$ supermarket at the significance level $(\mathrm{p}<0.01)$. The store's image can be considered an important predictor of the attitude towards a store's brand (SEMEIJN; RIEL; AMBROSINI, 2004).

\subsection{BRAND IMAGE AND ASSOCIATION}

Image also presented a positive divergent relationship with the brand association, both for manufacturers (H3a) as well as for the supermarket (H3b). The hypothesis (H3a) was confirmed at the significance level p <0.01) and H3b not confirmed. Manikandan (2012) attests that the store image can be expressed by dimensions based on quantities (9, 7, 6 and 3) of different factors (commodity, variety, climate, location, easy parking, friendly staff, etc.).

\subsection{DISTRIBUTION INTENSITY AND QUALITY}

The hypothesized relationship between distribution intensity and quality are statistically significant, both for manufacturers' brands (H4a) as for the supermarket ones 
Consumers can choose the channels of their choice based on price, product assortment and convenience as well as their own purchasing goals (economic, social or experiential) (ANSARI; MELA; NESLIN, 2008).

\subsection{DISTRIBUTION INTENSITY AND LOYALTY}

The hypotheses that address the relationship between distribution intensity and loyalty have similar results: not significant for manufactures' brands (H5a) and from supermarkets (H5b) at the level of $\mathrm{p}<0.05$. There is an ambiguity about the relationship between the sales of private labels and customer loyalty (AILAWADI; PAUWELS; STEENKAMP, 2008).

\subsection{DISTRIBUTION INTENSITY AND BRAND ASSOCIATION}

Distribution intensity presented the confirmation of the hypostheis (H6a) of manufactures' brands with brand association, and contrary to the non-confirmation of the hypothesis (H6b) of the distribution intensity of the supermarket's brands at significance level of $\mathrm{p}<0.05$. Therefore, in the case of food, a selective distribution may have a greater impact on the brand association (PEREIRA, 2001).

\subsection{ADVERTISING EXPENDITURES AND QUALITY}

The hypothesis (H7a) was rejected which is positively related to advertising spending on the perceived quality for the manufacturers' brand and $\mathrm{H} 7 \mathrm{~b}$ was accepted for the supermarket's brand at the significance level of $p<0.05$. We assumed that this divergence of results comes from the effectiveness of advertising expenditures related to the brands presented to respondents (KOTLER; KELLER, 2006).

\subsection{EXPENDITURES WITH ADVERTISING AND LOYALTY}

The positive relationship hypotheses between advertising expenditures and loyalty only presented significant result $(\mathrm{p}<0.05)$ for the case of supermarket's brand $(\mathrm{H} 8 \mathrm{~b})$. These expenditures, in the case of manufacturers' brands (H8a) are not significantly associated with brand loyalty. This result is related to the fact that private labels seek more exclusivity, their budgets are more selective regarding the media used than the independent stores selling manufacturers' brand. These will leave the advertising under the responsibility of manufacturers operating in more aggressive media, thus generating greater knowledge of these brands (AILAWADI; PAUWELS; STEENKAMP, 2008).

\subsection{EXPENDITURES ON ADVERTISING AND BRAND ASSOCIATION}

Similarly the relationship with advertising expenditures and loyalty, the hypothesis (H9A) was not supported that positively relates to advertising expenditures with the 
association to the manufacturers' brand, and (H9b) was accepted which positively relates advertising expenditures to Carefour's brands at the significance level. The way consumers perceive brands is the determinant key of long-term business relationship (LOW; LAMB, 2000).

\subsection{NEGOTIATED PRICES AND QUALITY}

Price negotiation is another dimension not presenting significant relationship with the quality construct. Both for manufacturers (H10A), as for the supermarket's brand (H10A), the results were not significant $(p>0.05)$. And in fact, the coefficient in the case of the manufactures' brands was contrary to the expected, that is, positive and not negative. One reason for this is that promotions (negotiated prices) appear to be inherent and typical of manufacturers' strategies without a negative effect on brands (SWINKER; HINES, 2006).

\subsection{NEGOTIATED PRICES AND BRAND ASSOCIATION}

Price negotiation did not present a positive and significant relationship with brand association, both for manufactures (H11a) at the level of $\mathrm{p}<0.1$, as well as for supermarket's brands (H11b). The negotiated prices are a practice carried out by both manufacturers' brands and by their own to renew its shelves with the arrival of new purchases. Under these conditions, the consumer's association to the brand is the same for both brands, without there being a negative impact. Consumers who want to save money can do so in two ways: one is that they can purchase the product by a manufacture's brand doing a "promotion", and the other way is that they can choose a from the supermarket's brand, practicing a lower price (without promotion) in relation to the manufacture's brand. We emphasize here that the consumer despite having a common objective to save money, have different attitude when purchasing manufacturers brands versus private label (MANIKANDAN, 2012).

\subsection{QUALITY AND BRAND EQUITY}

From this item on, the analysis goes from the relationship between antecedents (marketing mix components of the enterprises) and brand equity dimensions, to the analysis of the results of the hypotheses test between the determinants (dimensions) and brand value (brand equity). The first relationship analyzed is the one between quality and brand equity. The results show that the quality construct, besides not presenting a significant constant relationship with the antecedents, has an influence on the value of brands, whether it be the manufacturers' (H12a) or supermarket's (H12b). We can infer from the sample that quality is related to brand equity, as this concept of quality is consistent in the food segment (CHEN; GREEN, 2009). 


\subsection{LOYALTY AND BRAND EQUITY}

Immediately brand loyalty did not appear as a consistent determinant of the value of brands (brand equity). In the case of loyalty to manufacturers' brands hypothesis (H13a) was not accepted, though, H13b was accepted, confirming the existence of a positive and significant relationship at $\mathrm{p}<0.05$. This result reflects the fact that loyalty to the brand equity of manufacturers and supermarket's brands is due to the experience (buy or use) of these brands (KOTLER; KELLER, 2006).

\subsection{BRAND ASSOCIATIONS AND BRAND EQUITY}

Similar to the results of the hypothesis tests between the perceived quality and brand equity, the tests for hypotheses on the influence of brand association on brand equity presented significant results for the case of manufacturers' brands (H14a) at the level of $\mathrm{p}$ $<0.001$ and for the supermarket's brand $(\mathrm{H} 14 \mathrm{~b} ; \mathrm{p}<0.05)$. This last result is due to the fact that competition for the attention of consumers is similar in intensity between the supermarket and manufacturers' brands, so that brand association is not a differentiating element of brand equity between these brands.

This evidence must be observed by managers and academics in future studies and current management practices, since the results presented show that the elements of the marketing mix, when applied in the context of food brands, can deliver differentiated results and impacts on the antecedents of the brand equity of the manufacturers and supermarket's brands. Similarly, the results here are different by authors Yoo Donthu and Lee (2000) who studied three product categories (TV sets, video camera and athletic shoes) in which only the distribution intensity is not supported with respect to knowledge and associations of selected brands in their study. That is, the results on the formation of brand equity must be relativized to the context and the type of products mentioned.

\section{FINAL CONSIDERATIONS}

Companies have given increasing attention to the issue of the brand as a competitive advantage factor, possibly predict future results. A significant part of the literature on brand management, the example of Aaker (1991), Keller (1993) and De Chernatony and McDonald (2003), discuss strategies for creating value for the brand. Studies on measures of brand equity based on the client have been tested in different practical and academic contexts, verifying whether these strategies are being successful or not.

The use of the multidimensional scale to measure brand equity can be used both to establish the relative position of the brands in the market, as it can, through a series of steps of 
a specific brand, to identify how it reacts to the marketing actions taken by the company or by competitors. In addition to an overall assessment of brand equity based on the consumer, the multidimensional scale proposed by Yoo and Donthu (2001) allows to evaluate individually the performance of the brand in each dimension, which can serve to guide, more specifically, the actions needed to increase the value of brand equity.

However Ailawadi et al (2003) and Atilgan et al (2009) claim that it is unlikely, if not impossible, to get through brand equity based on the consumer a measure that satisfies all the characteristics of a brand, ideally, and that provides interesting stimulating instructions for managerial practices. However, in addition to internal company information on financial performance, managers can benefit from the monitoring of the marketing mix variables (price, store's image, distribution intensity, advertising expenditures and promotional prices). They precede and contribute to the formation of the dimensions of brand equity (perceived quality, brand loyalty, knowledge and brand associations) and to strengthen the brand equity and management of food brands in general.

We believe, therefore, that by adapting marketing strategies according to the dimensions of brand equity it is possible to design solutions to deliver value to the consumer of clothing. More specifically, managers must develop their marketing mix programs to manage and observe the causal relationships with the dimensions of brand equity, the perceived quality, brand loyalty, knowledge and associations to supermarket brands.

The results of this study clearly show the specifics of private brands or manufacturers. They show that the antecedents and dimensions exert influence on differentiated brands and manufacturers themselves. These different influences also differ depending on the assessed sector, such as the example demonstrated by Castelo et al. (2014) in the case of manufacturers' brands and private labels in the clothing industry. These dimensions also impact the brand equity moderately. This means, of course, two challenges that we meet: one for marketers who can take advantage to adopt more focused and selective marketing strategies to increase their brand equity; another for researchers so that studies may be develop which can contribute to a redefinition of the dimensions of brand equity for distributors' brands, which in this case here appear unlimited related to global brand equity of these brands.

\subsection{LIMITATIONS AND SUGGESTIONS FOR FUTURE RESEARCH}

This research brings some contributions to organizations in general, especially for those who work in the food segment sold in Carrefour supermarket. However, it also has limitations 
that can be explored in future studies. Initially, one can record the fact that the study only took place in the city of Fortaleza with private brands of the Carrefour supermarket. Future research developed into broader fields and with more products with private labels can help assess the validity of the conclusions presented here.

A second limitation of this study refers to the use of awareness measures, from the metrics proposed by Yoo, Donthu and Lee (2000) and not the objective data of the marketing efforts of companies. It would be significant, from a management perspective, using marketing data from secondary sources, such as scanner data and reports of published researches or data of the companies holding the brands submitted to the assisted recall test of this study or even other brands not selected for this study.

Finally, we used a field survey method based on a structured questionnaire to test research hypotheses. This method is not always clear in the inferences and causalities that are allowed to establish. To investigate more rigorously the causal impact of each marketing effort and food brands in the brand equity formation process, researchers could design and conduct experiments manipulating the level of marketing effort. Therefore, future researches are called on in order to examine the effect of the real marketing variables to determine the brand equity of supermarket's brands, in a longitudinal context.

\section{REFERENCES}

AAKER, D. A. Managing brand equity: capitalizing on the value of a brand name. New York: Free Press, 1991.

AAKER, D. A.; BREL, A. C. Brand equity and advertising. Hillsdale: Lawrence Arlbaum Associates, 1993.

AAKER, D. A.; JACOBSON, R. The financial information content of perceived quality. Journal of Marketing Research, v.31, n.5, p.191-201, 1994.

ACNIELSEN. The power of private label: a review of growth trends around the world. Executive News Report from ACNielsen Global Services, Sept 2005.

AILAWADI, K. L.; LEHMANN, D. R.; NESLIN, S. A. Revenue premium as an outcome measure of brand equity. Journal of Marketing, v. 67, 4, p. 1-17, 2003.

AILAWADI, K. L.; PAUWELS, K. E. M.; STEENKAMP, J. B. Private-label use and store loyalty. Journal of Marketing, v.72, p. 19-30, 2008.

ALBA, J. W.; HUTCHINSON, J. W. Dimensions of consumer expertise. Journal of Consumer Research, v. 13, n.4, p. 411-454, 1987. 
ANSARI, A.; MELA, C.; NESLIN, S. Customer channel migration. Journal of Marketing Research, v. 45, n.1, p. 60-76, 2008.

ANSELMSSON, J.; JOHANSSON, U.; PERSSON, N. Understanding price premium for grocery products: a conceptual model of customer-based brand equity. Journal of Product at Brand Management, v. 16, n. 6, p. 401-414, 2007.

ARCHIBALD, R. B.; HAULMAN, C. A.; MOODY JUNIOR, C. E. Quality, price, advertising and published quality rating. Journal of Consumer Research, v.9, n. 4, p. 347356, 1983.

ATILGAN, E.; AKSOY, S.; AKINCI, S; KAYNAK, E. Customer-based brand equity for global brands: a multinational approach. Journal of Euromarketing, v.18, p. 115-132, 2009.

ATILGAN, E.; AKSOY, S.; AKINCI, S; KAYNAK, E. Determinants of the brand equity: a verification approach in the beverage industry in Turkey. Marketing Intelligence \&

Planning, v. 23, n. 3, p. 237-248, 2005

BELCH, G. E.; BELCH, M. A. Advertising and promotion, Boston: McGraw-Hill Irwin, 2007.

CASTELO, J. S. F.; COELHO, A. F. M.; CABRAL, J. E. O. Análise comparativa dos antecedentes e dimensões do brand equity entre marcas de fabricantes e marcas próprias no setor de vestuário. Gestão \& Produção, v.21, n.1, p.19-32, 2014.

CHEN, H. C.; GREEN, R. D. Marketing mix and branding: competitive hypermarket strategies. International Journal of Management and Marketing Research, v.2, n. 1, p. 17-34, 2009.

CUNNINGHAM, R. M. Customer loyalty to store and brand. Harvard Business Review, v. 3, n. 9, p. 127-37, 1961.

DATTA, P. R. The determinants of brand loyalty. Journal of American Academy of Business, Cambridge, v.3, n. 1-2, p. 138-144, 2003.

DECHERNATONY, L.; MCDONALD, M. Creating powerful brands in consumer: service and industrial markets. Oxford: Elsevier, 2003.

FERRIS, P.; OLIVER, J.; KLUYVER, C. The relationship between distribution and market share. Marketing Science, v.8, n. 2, p. 107-127, 1989.

FRANK, R. E.; BOYD, H. W. Are The private-brand prone grocery customer really different? Journal of Advertising Research, v.5, n. 4, p. 27-35, 1965.

GREWAL, D.; LEVY, M. Retailing research: past, present, and future. Journal of Retailing, v. 83, n.4, p. 447-464, 2007.

HAIR JUNIOR, J. F. et al. Análise multivariada de dados. 5. ed. Porto Alegre: Bookman, 2005. 
HANSEN, K.; SINGH, V.; CHINTAGUNTA, P. Understanding store-brand purchase behavior across categories. Marketing Science, v. 25, n.1, p. 75-90, 2006.

KAMAKURA, W. A.; RUSSELL, G. J. Measuring brand value with scanner data. International Journal of Research in Marketing, v.10, p. 9-21, 1993.

KELLER, K. L. Conceptualizing, measuring, and managing customer-based brand equity. Journal of Marketing, v.57, p. 1-22, 1993.

KIRMANI, A.; WRIGHT, P. Money talks: perceived advertising expenditures and expected product quality. Journal of Consumer Research, v.16, p. 344-353, 1989.

KOTLER, P.; KELLER, K. L. Administração de marketing, 12. ed. São Paulo: Pearson Prentice Hall, 2006.

LOW, G.S.; LAMB, C. W. The measurement and dimensionality of brand association, The Journal of Product and Brand Management, v.9, n.6, p.350-367, 2000.

MALHOTRA, N. K. Pesquisa de marketing: uma orientação aplicada. Porto Alegre: Bookman, 2012.

MANIKANDAN, M. K. M. Theory building on private label brands: a literature review. The IUP Journal of Brand Management, v.9, n. 2, p. 64-77, June 2012.

MATTAR, F. N.; OLIVEIRA, B.; MOTTA, S. L. S. Pesquisa de marketing: metodologia, planejamento, execução e análise. 7a. ed. Rio de Janeiro: Elsevier, 2014.

MUNIZ, K. M.; MARCHETTI, R. Z. Brand personality dimensions in the Brazilian context. Brazilian Administrative Review, v. 9, p. 168-188, 2012.

MYERS, J. G. Determination of private brand attitudes. Journal of Marketing Research, v.4, n. 1, p. 73-81, 1967.

PEREIRA, I. Marcas de Supermercado. Revista de Administração de Empresas, v.41, n.1, p.16-27, 2001.

OLIVER, R. L. Satisfaction: a behavioral perspective on the consumer. New York: McGrawHill, 1997.

OLSON, J. C. Price as an informational cue: effects on product evaluations. In: WOODSIDE, A.G.; SHETH, J. N.; BENNETT, P. D. (Eds.).Consumer and industrial buying behavior. New York: Elsevier, 1977. p. 267-286.

PLMA. Private Label Manufacturers Association. International private label yearbook 2007. Disponível em:< http://www.plmainternational.com/industry-news/private-labeltoday>. Acesso em: 13 de Abril de 2014.

QUELCH, J. A.; HARDING, D. Brands versus private label: fighting to win. Harvard Business Review, v.74, n. 1, p. 99-109, 1996. 
RAO, A. R.; MONROE, K. B. The effect of price. brand name, and store name on buyers' perceptions of product quality: an integrated review. Journal of Marketing Research, v. 26, p. 351-357, 1989.

RUMELT, R.; SCHENDAL, D.; TEECE, D. Strategic management and economics. Strategic Management Journal, v. 12, p. 5-29, 1991.

SAYMAN, S.; RAJU J. S. How category characteristics affect the number of store brands offered by the retailer: a model and empirical analysis. Journal of Retailing, v. 80, n. 4, p. 279-287, 2004.

SEMEIJN, J.; RIEL, A.; AMBROSINI, A. Consumer evaluations of store brands: effects of store image and product attributes, Journal of Retailing and Consumer Services, v.11, n.4, p. 247-258, 2004.

SHETTY, A. S.; S. MANOHARAN. The battle of private and national brands: strategies to win a losing battle against the private brands in India. IUP Journal of Business Strategy, v.9, n. 3, p. 32-45, 2012.

SCHULTZ, D. E. Getting to the heart of the brand. Marketing Management, v. 10, p. 8-9, 2001.

SHIMP, T. A. Advertising, promotion, and supplemental aspects of integrated marketing communications. 4. ed. Orlando: Dryden, 1997.

SHIMP, T. A. Advertising and promotion: supplemental aspects of integrated marketing communications. 5. ed. Orlando: Drydren Press, 1999.

SHOCKER, A. D.; WEITZ, B. A. Perspective on brand equity principles and issues: In: LEUTHESSER, L. (Ed.). Defining, measuring, and managing brand equity. Ed. Lance, 1988. Report, n. 88-104.

SMITH, D. C. Brand extension and advertising efficiency: what can and cannot be expected. Journal of Advertising Research, v. 32, p. 11-20, 1992.

SNIPES, R. L.; THOMSON, N. F.; OSWALD, S. L. Gender bias in customer evaluation of service quality: an empirical investigation. Journal of Services Marketing, v.20, n. 4, p. 274-284, 2006.

SRIVASTAVA, R. K.; SHOCKER, A. D. Brand equity: a perspective on its meaning and measurement. Marketing Science Institute, Cambridge, MA, Working Paper, p. 91-124, 1991.

STEENKAMP J.; VAN HEERDE H.; GEYSKENS I. What makes consumers willing to pay a price premium for national brands over private labels? Journal of Marketing Research v.47, n.6, p.1011-1024, 2010.

SWINKER, M. E.; HINES, J. D. Understanding consumers' perception of clothing quality: a multidimensional approach, International Journal of Consumer Studies, v.30, n. 2, p. 218 223, 2006. 
WALSH, G.; MITCHELL, V. W. Demographic characteristics of consumers who find it difficult to decide. Marketing Intelligence and Planning, v. 23, n. 2-3, p. 281-295, 2005.

YOO, B.; DONTHU, N. Developing and validating a multidimensional consumer-based brand equity scale. Journal of Business Research, v. 52, n. 1, p. 1-14, 2001.

YOO, B.; DONTHU, N.; LEE, S. An examination of selected marketing mix elements and brand equity. Journal of Academy of Marketing Science, v. 28, n. 2, 195-211, 2000.

ZEITHAML, V. A. Consumer perceptions of price, quality, and value: a means-end model and synthesis of evidence. Journal of Marketing, v.52, n. 3. p. 2-22, 1988. 